\title{
Methodology for classification and typology development of regions with a view to promoting export of agricultural products
}

\author{
Lyudmila Medvedeva* and Elena Ivanova \\ Don State Technical University, 344000, Rostov-on-Don, Russia
}

\begin{abstract}
The work is aimed at the development of methodological support for regions' typology development in order to group them according to the essential features and calculate the integral indicator. The unique technique is suggested by the authors which includes five stages, all of them supplementing each other. Properly developed typology of regions helps to define the group which the region belongs to, and, on the basis of this, to develop measures to improve the efficiency of agricultural enterprises' activity in this area and expand the economic potential of export operations, taking into account the clear justification. The specific indicators for ranking regions by groups are determined by the authors in the article. The significance of this methodology development is justified within the framework of implementation of state support for the export of agro-industrial products.
\end{abstract}

\section{Introduction}

In current economic conditions, the problematic aspects remain in issues related to the development of exports of agro-industrial products. It is important to understand that the accurate assessment of the economic potential of territories, which carry out certain activities, is required to implement the support policy for this economic sector and develop the actions of manufacturers. Thus, the economic task of classifying and typologizing the country regions includes forming their groups according to predetermined essential features in order to determine and expand the potential of export of agricultural products [1-4].

For the purpose of this study, the typology of subjects should be understood as the establishment of certain relationships between regions with regard to their economic potential for the development of agricultural export transactions. From the perspective of strategic development of the modern economy, it is the export of agro-industrial products that can be considered as the most important indicator of growth and stability. There is a need to ensure the export of agro-industrial products at the level of at least $20 \%$ of GDP in order to increase the level of competitiveness of the Russian economy. Moreover, the fish products are in the greatest demand for export [5-7].

*Corresponding author: milla1988@mail.ru 
The main purpose of the study is to develop a science-based methodology aimed at classifying regions to assign them to the specific group, which characterizes the strategic direction of the given region development including production and sales of agricultural products, both on the territory of the Russian Federation and for export.

It is worth mentioning that the issues of development and testing of methodology for classification and typology development of regions has been studied by economists and practitioners for quite some time, but the development of methodological support for this process in light of narrowly defined purpose remains under-explored.

\section{Materials and methods}

It has been found that classification and typology of regions including their assignment to a certain group according to the essential features helps to accurately develop the state support policy for those territories which need it. Clearly, this stage represents one of the program elements and the part of the set of mechanisms for state support of the export sales of agricultural products [8].

To conduct the classification in the study, the groups of regions and criteria for their classification are proposed, the method for calculating the integral indicator of region potential and region ranking order are defined. Thus, it is proposed to develop the typology of regions using horizontal and vertical analysis, index method, correlation analysis, calculation of average indicators and other analysis methods.

\section{Results}

The essence of the proposed methodological tool box includes developing regions' typologies meaning the division of regions into groups. The area of activity of fishing industry enterprises is chosen as the example for methodology description because it is one of the most promising and developing sectors in current economic conditions [9].

In our view, the regions should be grouped as follows:

- regions with potential for fish and seafood production;

- regions with potential for processing fish and fishery products;

- regions with potential for exporting fish and seafood;

- regions with potential for equipment production for the sector of fish and seafood production;

- regions with potential for personnel training for the fish and seafood industries.

The typology of regions is developed on the basis of identifying several essential features (indicators) and calculating the integral indicator of the selected group.

It is suggested to calculate the integral indicators using five interrelated stages:

- selection of the set of indicators which should serve as the basis for group creation and integral indicator calculation;

- implementation of region ranking process using the clustering technique (it is possible to use the automated product STATISTICA 12);

- modification of previously selected indicators and their translation into a scoring system in order to ensure comparability; it is important to bear in mind that various indicators with different units of measurement can be used to construct the integral indicator;

- identification of the weight of each indicator using the expert assessment method;

- identification of the most efficient way to aggregate the indicators into one system [1013].

At the first stage, it is necessary to determine the most significant indicators that affect the output indicator. The selection of indicators is conducted with the use of correlation 
method. The value of the indicator above 0.5 shows close link and is selected for the next stage analysis.

The use of correlation analysis tools in the process of typology development makes it possible to determine a clear link between all the studied indicators. It may be noted that it is the correlation analysis that contributes to the determination of factors which have a greater impact on the output indicator, identification of cause-and-effect relationships, study of the significance of relationship parameters in the process of integral indicator calculation.

The ranking of regions by the groups, which were proposed in the research process, should be conducted at the second stage. It is possible to use cluster analysis tools and the STATISTICA 12 program [14-16].

The third stage of the methodology for regions' typology development includes modifying previously selected indicators and translating them into a scoring system in order to ensure comparability.

The intervals are based on the calculation of maximum and minimum values of the studied set:

$$
h=\frac{x_{\max }-x_{\min }}{n}
$$

where $h$ is the interval length (the difference between maximum and minimum value of the main entity);

$n$ is the number of given groups.

The expert assessment of the weighting values of indicators (group indicators) is conducted at the fourth stage.

The integral indicator of the group is calculated at the fifth stage, which makes it possible to determine the level of potential.

$$
I P=\sqrt[a_{j}]{\left(P 1_{i} * b 1_{i}\right) *\left(P 2_{i} * b 2_{i}\right) *\left(P 3_{i} * b 3_{i}\right) * \ldots *\left(P a_{i} * b a_{i}\right)}
$$

Where $P 1_{i .,} P 2_{i, .} P 3_{i .}, P a_{\mathrm{i}}$ are the absolute indicators converted into the score of the corresponding group;

$-b 1_{i}, b 2_{i}, b 3_{i}, b a_{\mathrm{i}}$ represent the indicator weight in the group;

- $a_{i}$ is the number of analyzed group indicators.

The last task involves determination of the potential of regions forfish and seafood production, regions with potential for processing fish and fishery products, regions with potential for exporting fish and seafood, regions with potential for equipment production for the sector of fish and seafood production, regions with potential for personnel training for the fish and seafood industries.

Let us present in Table 1 the recommended set of indicators that can be used in the process of ranking regions by groups.

Table 1. The indicators used for ranking regions by groups

\begin{tabular}{|c|c|}
\hline Indicator & Description \\
\hline Fish production volume & $\begin{array}{c}\text { The volume of production is shown, both } \\
\text { in natural units and value terms }\end{array}$ \\
\hline Production of live fish, fresh or chilled & $\begin{array}{c}\text { The indicator includes the data on the } \\
\text { production of fish (live or chilled) }\end{array}$ \\
\hline Fish production including canned food & $\begin{array}{c}\text { Determination of potential assumes the } \\
\text { availability of production capacity for } \\
\text { product processing }\end{array}$ \\
\hline
\end{tabular}




\begin{tabular}{|c|c|}
\hline Number of port and repair bases & $\begin{array}{c}\text { The indicators showing logistical potential } \\
\text { of the region }\end{array}$ \\
\hline $\begin{array}{l}\text { Number of enterprises specializing in } \\
\text { fish farming }\end{array}$ & $\begin{array}{l}\text { The indicator shows the reproduction } \\
\text { process of the resource that needs to be } \\
\text { renewed }\end{array}$ \\
\hline Number of net making plants & \multirow{2}{*}{$\begin{array}{c}\text { The indicators showing logistical potential } \\
\text { of the region }\end{array}$} \\
\hline Number of trawler freezers & \\
\hline Number of research institutes of fishery & $\begin{array}{l}\text { The industry development potential is } \\
\text { always associated with research and } \\
\text { development activities of leading scientific } \\
\text { centers and educational organizations }\end{array}$ \\
\hline $\begin{array}{l}\text { Number of people employed in the sector } \\
\text { of fish and seafood production }\end{array}$ & $\begin{array}{l}\text { The indicator showing human capacity of } \\
\text { the region }\end{array}$ \\
\hline $\begin{array}{c}\text { Fish and seafood production capacity, } \\
\text { tons per day }\end{array}$ & \multirow[b]{2}{*}{$\begin{array}{l}\text { The indicator of infrastructure } \\
\text { development of the region }\end{array}$} \\
\hline $\begin{array}{l}\text { Production capacity for processing fish } \\
\text { and seafood, tons per day (tons per year) }\end{array}$ & \\
\hline $\begin{array}{c}\text { Number of people employed in the sector } \\
\text { of fish and seafood processing }\end{array}$ & $\begin{array}{l}\text { The indicator showing human capacity of } \\
\text { the region }\end{array}$ \\
\hline $\begin{array}{c}\text { Refrigeration and storage capabilities, } \\
\text { tons }\end{array}$ & $\begin{array}{c}\text { The indicator of infrastructure } \\
\text { development of the region }\end{array}$ \\
\hline $\begin{array}{l}\text { Number of enterprises engaged in export } \\
\text { of fish products }\end{array}$ & $\begin{array}{l}\text { Development of export potential is the } \\
\text { priority area for industry development }\end{array}$ \\
\hline Number of potential export markets & $\begin{array}{l}\text { Identification of development areas for } \\
\text { regional companies }\end{array}$ \\
\hline Number of logistics centers & $\begin{array}{c}\text { The indicators showing logistical potential } \\
\text { of the region }\end{array}$ \\
\hline $\begin{array}{l}\text { Number of manufacturers of } \\
\text { technological equipment for fish and } \\
\text { seafood production }\end{array}$ & \multirow{3}{*}{$\begin{array}{l}\text { The indicators of infrastructure } \\
\text { development of the region }\end{array}$} \\
\hline $\begin{array}{l}\text { Number of manufacturers of } \\
\text { technological equipment for fish and } \\
\text { seafood processing }\end{array}$ & \\
\hline Number of ship repair facilities & \\
\hline $\begin{array}{l}\text { Number of programs of secondary } \\
\text { vocational education for training } \\
\text { specialists for fishing industry }\end{array}$ & \multirow{4}{*}{$\begin{array}{l}\text { The indicators showing human capacity of } \\
\text { the region }\end{array}$} \\
\hline $\begin{array}{c}\text { Number of programs of higher education } \\
\text { for training specialists for fishing } \\
\text { industry }\end{array}$ & \\
\hline $\begin{array}{l}\text { Number of retraining center straining } \\
\text { specialists for fishing industry }\end{array}$ & \\
\hline $\begin{array}{l}\text { Number of centers of excellence training } \\
\text { specialists for fishing industry }\end{array}$ & \\
\hline $\begin{array}{l}\text { Number of information support centers } \\
\text { for fishing industry }\end{array}$ & $\begin{array}{l}\text { Development of forms of support for } \\
\text { producers in the region, taking into } \\
\text { account the industry specifics }\end{array}$ \\
\hline $\begin{array}{l}\text { Capacity of marine terminals, tons per } \\
\text { day }\end{array}$ & $\begin{array}{c}\text { The indicator of infrastructure } \\
\text { development of the region }\end{array}$ \\
\hline
\end{tabular}

Thus, in our view, suggested indicators should be divided into the following groups: 
Group 1. Potential for fish and seafood production:

- number of trawler freezers;

- number of research institutes of fishery;

- number of people employed in the sector of fish and seafood production;

- fish and seafood production capacity, tons per day;

- fish and seafood production volume, tons per year;

- number of enterprises specializing in fish farming.

Group2. Potential for processing fish and fishery products:

- production capacity for processing fish and seafood, tons per day (tons per year);

- number of people employed in the sector of fish and seafood processing;

- refrigeration and storage capabilities, tons;

- fish production volume, tons per year;

- fish production including canned food, tons per year.

Group3. Potential for exporting fish and seafood:

- capacity of marine terminals, tons per day;

- number of enterprises engaged in export of fish products;

- number of potential export markets;

- number of logistics centers.

Group4. Potential for equipment production for the sector of fish and seafood production:

- number of ship repair facilities;

- number of manufacturers of technological equipment for fish and seafood processing;

- number of port and repair bases;

- number of net making plants.

Group 5.Potential for personnel training for the fish and seafood industries:

- number of programs of secondary vocational education for training specialists for fishing industry;

- number of programs of higher education for training specialists for fishing industry;

- number of retraining centers training specialists for fishing industry;

- number of centers of excellence training specialists for fishing industry.

Itshouldbenotedthatthesetofsuggestedindicatorshasaclearindustryspecificsandcanbesuppl ementedorimproved according to the goals and objectives which should be defined in the process of region potential assessment.

\section{Conclusions}

The presented methodological toolbox designed for classification and typology development of regions according to essential features can serve as a universal mechanism aimed at assessing the territory potential with reference to established goals and objectives.

Thus, the proposed methodology will help to resolve the following problems associated with the development of regions in terms of expanding the potential of export operations of agricultural products:

- science-based grouping of regions within the framework of those support programs that are required considering the identified region potential;

- assessment and strategy formulation for development of the territory, bearing in mind that the strategic components may be different;

- justification of efficiency of the development direction taken by the region;

- updating the regional policy with reference to the identified development potential in the short and long terms;

- organization of cluster development zones. 
In conclusion, it should be mentioned that increasing the sales volume of products of the Russian agro-industrial complex in the world market is necessary to develop competitive advantages and stabilize the Russian economy in the long run.

However, there is a need to develop methodological tools that would help to implement the support policy of individual organizations and regions, which decide to expand their presence in the international market, in a more sustainable manner and at a high level of detail.

\section{References}

1. T. Marwa, A. Bashir, M. Azwardi, H. Thamrin, International Journal of Economics and Business Administration 5(2), 69-82 (2017)

2. N. Reshetnikova, M. Magomedov, Smart Innovation, Systems and Technologies 138, 399-408 (2020)

3. E. Muratova, D. Muratov, E. Kravchenko, A. Sukhoveeva, O. Andreeva, E3S Web of Conferences 210, 05010 (2020).

4. L. Medvedeva, IOP Conference Series: Earth and Environmental Science 548(2), 1-5 (2020).

5. Z. Gornostaeva, Y. Sorokina, Lecture Notes in Networks and Systems 73, 177-184 (2020)

6. V. Joao, Science of the Total Environment 68820, 346-360 (2019).

7. M. Kabanenko, L. Dubrova, N. Andreeva, L. Orekhova, E. Ivanova, E3S Web of Conferences 175, 06005 (2020)

8. V. Mazur, K. Barmuta, S. Demin, E. Tikhomirov, M. Bykovskiy, International Journal of Economics and Financial 6 (1S), 270-274 (2016).

9. Z. Gornostaeva, Lecture Notes in Networks and Systems (73), 287-295 (2020).

10. V. Borisova, E. Panfilova, P. Zhukov, S. Matulis, V. Matveev, V. Teymurova, International Journal of Management and Business Research 9(1), 158-169 (2019)

11.Z. Gornostaeva, I. Kushnaryova, E. Alekhina, Advances in Intelligent Systems and Computing 726, 207-216 (2019)

12. Z. Gornostaeva, N. Lazareva, M. Bugaeva, O. Gribova, N. Zibrova, International Journal for Quality Research 13 (2), 301-314 (2019)

13. I. Terenina, D. Kostoglodov, L. Kiyanova, O. Usatkina, International Journal of Economics and Business Administration, 7, 325-338(2019).

14. O. Godina, Y. Kosenkova, L. Maksimenko, Y. Mezentseva, T.Shcherbakova, Advances in Intelligent Systems and Computing 726, 118-127 (2019).

15. K. Barmuta, O. Grishchenko, E3S Web of Conferences 175, 08003 (2020).

16. A. Solonenko, L. Medvedeva, Y. Mostovaya,E3S Web of Conferences 175, 1-8(2020) 